\title{
Investigation of the Impact of Father's Occupation on the Subjective Well-being of College Students with Left-behind Experience*
}

\author{
Zhengzheng Chen \\ Recruitment and Employment Office \\ Sichuan University of Arts and Science \\ Dazhou, China 635000
}

\begin{abstract}
Objective: to understand the influence of father's occupation on subjective well-being of college students with left-behind experience, and to provide reference for colleges to carry out psychological crisis intervention for college students. Methods: Through overall randomized questionnaire survey, evaluation analysis is conducted on 563 college students by using the General Well-Being (GWB) Scale and the self-edited basic information questionnaire of subject. The results showed that there was a significant difference in the overall well-being of students with fathers working and those with fathers farming at home, with fathers working and fathers as laid-off workers, with fathers as civil servants and fathers as laid-off workers $(P<0.05)$; the difference in overall well-being of college students with fathers as teacher and fathers as laid-off workers, fathers farming at home and fathers as self-employers is not significant $(P>0.05)$. There is a very significant difference in overall happiness of students with fathers as self-employers and fathers as laid-off workers, with fathers as farms and fathers as laid-off workers. $(P<\mathbf{0 . 0 1})$ The highest score on overall happiness occurs in the father's occupation as teachers, followed by the fathers as civil servants, while the lowest score occurs in the students with left-behind experience and those with fathers farming at home; we should strengthen the education on subjective happiness of college students with fathers farming at home and with left-behind experience.
\end{abstract}

Keywords-father's occupation; students with left-behind experience; subjective well-being; investigation

\section{INTRODUCTION}

With the rapid development of urbanization and industrialization, urban construction requires a large number of labors, and factory production requires a large number of industrial workers. In China's rural areas, there are many plateau mountains with poor natural environment, barren land, and backward economy, so the income of farmers is low; in order to improve the quality of family life, a large number of rural male surplus laborers left their hometowns to work in cities and eastern factories. They have made great contributions to China's urban construction and economic

*Fund Project: One of the results of the serial research projects (15SA0104) of Sichuan Provincial Department of Education 2015 Humanities and Social Sciences Key Research Project "Study on Subjective Well-being and the Long-term Mechanism of Psychological Intervention of Female College Students with left-behind Experience". development. However, because they do not have skills, they can only rely on hard work, resulting in low income. They are unable to support their children to live and study in the city, so their children can only stay in the hometown to live with their grandparents, and become the special group of rural left-behind children. Some of these rural left-behind children have the luck of entering the university through their own efforts. For such group, because of the long-term separation from fathers in their childhood, the fatherly love required for their growth has been mercilessly deprived, and the family structure without father and fathers' occupations may have an impact on their subjective well-being. How to improve their subjective well-being has become an important issue in the mental health education of colleges and universities in the new era. Reviewing the previous studies, the research on the influence and intervention of the father's occupation on the subjective well-being of college students with left-behind experience is rare. Therefore, this study aims to investigate the influence of father's occupation on the subjective well-being of college students with left-behind experience, and propose relevant countermeasures and suggestions, so as to provide data support for the influence of father's occupation on the subjective well-being of college students with left-behind experience and the improvement of their subjective well-being.

\section{OBJECT AND METHOD}

\section{A. Research Objects}

Cluster sampling was adopted to conduct questionnaire survey among college students of Dazhou Vocational and Technical College, Sichuan University of Arts and Science and Chongqing University. A total of 600 questionnaires were distributed, and 583 questionnaires were collected, with the recovery rate $97.2 \%$; 565 questionnaires were valid, and the effective rate is $96.9 \%$. There are 400 female students and 165 male students; 387 rural students and 178 urban students; 148 high vocational college students, 277 ordinary second tier college students and 140 key university students.

\section{B. Research Tools}

The survey was conducted through unified questionnaire, which includes two parts: the basic information of the 
subjects and the overall well-being scale (GWB). The basic information questionnaire for the subjects was designed by the author, including the gender, family structure, school type, family address, father's occupation, father's education level, whether the father went out to work, whether the father was farming at home, whether the father was laid off, whether the father was an self-employer, whether the father is a civil servant, and whether the father is a teacher, which is mainly used to understand the basic situation of the subject. The General Well-Being Scale (GWB) was developed by the National Center for Health Statistics and used extensively in China to measure the feeling of happiness. The scale includes six subjective well-being factors such as satisfaction and interest in life, health concerns, depressed or happy mood, energy, relaxation and tension, and the control of emotions and behaviors. The higher the score is, the higher the overall happiness is. There are 25 topics in the original scale. Since the 19 th to 25 th items are not suitable for the college students with left-behind experience, the first 18 items are selected according to actual needs.

\section{Statistical Analysis}

The literature data method, questionnaire survey method, individual interview method and other methods were used to collect the relevant information of college students with leftbehind experience. Then the author revised the basic information questionnaire and GWB of the subjects, screened the 583 collected questionnaires, and eliminated the invalid questionnaires. Then, by using SPSS 17.0 statistical software, 565 valid questionnaires were entered and statistically analyzed. It mainly adopts statistical methods such as descriptive analysis and pairwise comparison using LSD-t test with $\mathrm{P}<0.05$ as the difference, which has statistical significance.

\section{RESEARCH RESULTS}

TABLE I. COMPARISON OF DIFFERENCES BETWEEN COLLEGE STUDENTS WITH FATHERS AS WORKERS AND FATHERS FARMING AT HOME

\begin{tabular}{|c|c|c|c|c|c|c|c|}
\hline & $\begin{array}{c}\text { satisfaction and } \\
\text { interest in life } \\
(\mathrm{M} \pm \mathrm{S})\end{array}$ & $\begin{array}{c}\text { health } \\
\text { concerns } \\
(\mathbf{M} \pm \mathbf{S})\end{array}$ & $\begin{array}{r}\text { energy } \\
(\mathbf{M} \pm \mathbf{S})\end{array}$ & $\begin{array}{c}\text { depressed or } \\
\text { happy mood } \\
(\mathrm{M} \pm \mathrm{S})\end{array}$ & $\begin{array}{l}\text { the control of emotions } \\
\text { and behaviors } \\
(M \pm S)\end{array}$ & $\begin{array}{c}\text { relaxation } \\
\text { and tension } \\
(\mathrm{M} \pm \mathrm{S})\end{array}$ & $\begin{array}{c}\text { overall } \\
\text { well-being }\end{array}$ \\
\hline $\begin{array}{l}\text { fathers working } \\
(\mathrm{n}=259)\end{array}$ & $6.32 \pm 1.58$ & $10.20 \pm 3.28$ & $14.90 \pm 3.78$ & $19.60 \pm 4.24$ & $11.23 \pm 2.32$ & $18.44 \pm 3.32$ & $80.68 \pm 10.94$ \\
\hline $\begin{array}{l}\text { fathers farming } \\
(\mathrm{n}=136)\end{array}$ & $6.58 \pm 1.60$ & $9.99 \pm 3.42$ & $14.74 \pm 3.69$ & $19.19 \pm 4.30$ & $11.27 \pm 2.17$ & $18.16 \pm 3.30$ & $79.93 \pm 9.41$ \\
\hline $\mathrm{t}$ & 1.268 & 0.083 & 0.018 & 0.070 & 1.913 & 0.012 & 3.967 \\
\hline $\mathrm{P}$ & 0.261 & 0.773 & 0.892 & 0.791 & 0.167 & 0.914 & $0.047^{*}$ \\
\hline
\end{tabular}

a. Note: * indicates $\mathrm{P}<0.05$, ** indicates $\mathrm{P}<0.01$, and $* * *$ indicates $\mathrm{P}<0.001, \mathrm{M}$ refers to the average, $\mathrm{S}$ stands for the standard deviation, and $\mathrm{n}$ refers to the number of people, similarly hereinafter.

It can be seen from "Table I" that there is no significant difference in the cognition of the six factors such as satisfaction and interest in life between the students with fathers as migrant workers and fathers farming at home $(\mathrm{P}>0.05)$, but there is a significant difference in overall wellbeing $(\mathrm{P}<0.05)$.

TABLE II. COMPARISON OF DIFFERENCES BETWEEN STUDENTS WITH FATHERS WORKING AND FATHERS AS LAID-OFF WORKERS

\begin{tabular}{|c|c|c|c|c|c|c|c|}
\hline & $\begin{array}{c}\text { satisfaction and } \\
\text { interest in life } \\
(\mathrm{M} \pm \mathrm{S})\end{array}$ & $\begin{array}{c}\text { health } \\
\text { concerns } \\
(\mathbf{M} \pm \mathbf{S}) \\
\end{array}$ & $\begin{array}{c}\text { energy } \\
(\mathbf{M} \pm \mathbf{S})\end{array}$ & $\begin{array}{c}\text { depressed or } \\
\text { happy mood } \\
(\mathrm{M} \pm \mathrm{S}) \\
\end{array}$ & $\begin{array}{l}\text { the control of emotions } \\
\text { and behaviors } \\
(\mathrm{M} \pm \mathrm{S})\end{array}$ & $\begin{array}{c}\text { relaxation and } \\
\text { tension } \\
(\mathrm{M} \pm \mathrm{S}) \\
\end{array}$ & $\begin{array}{c}\text { overall } \\
\text { well-being }\end{array}$ \\
\hline $\begin{array}{l}\text { fathers working } \\
(\mathrm{n}=259)\end{array}$ & $6.32 \pm 1.58$ & $10.20 \pm 3.28$ & $14.90 \pm 3.78$ & $19.60 \pm 4.24$ & $11.23 \pm 2.32$ & $18.44 \pm 3.32$ & $\begin{array}{l}80.68 \pm 10.9 \\
4\end{array}$ \\
\hline $\begin{array}{l}\text { fathers as laid-off } \\
\text { workers }(n=33)\end{array}$ & $6.42 \pm 2.03$ & $10.33 \pm 3.88$ & $15.33 \pm 4.55$ & $20.33 \pm 4.94$ & $11.36 \pm 2.78$ & $18.64 \pm 4.07$ & $\begin{array}{l}82.42 \pm 14.4 \\
4\end{array}$ \\
\hline $\mathrm{t}$ & 5.336 & 4.934 & 2.833 & 0.651 & 0.648 & 0.920 & 4.524 \\
\hline $\mathrm{P}$ & $0.022^{*}$ & $0.027^{*}$ & 0.093 & 0.420 & 0.421 & 0.338 & $0.034^{*}$ \\
\hline
\end{tabular}

It can be seen from "Table II" that there is significant difference in the cognition of the 2 factors including satisfaction and interest in life and health concerns between the students with fathers as migrant workers and fathers as laid-off workers $(\mathrm{P}>0.05)$, but the difference in cognition of the rest 5 factors is not significant $(\mathrm{P}<0.05)$.

TABLE III. COMPARISON OF DIFFERENCES BETWEEN STUDENTS WITH FATHERS AS SELF-EMPLOYER AND FATHERS AS LAID-OFF WORKER

\begin{tabular}{|c|c|c|c|c|c|c|c|}
\hline & $\begin{array}{c}\text { satisfaction and } \\
\text { interest in life } \\
(\mathrm{M} \pm \mathrm{S})\end{array}$ & $\begin{array}{c}\text { health } \\
\text { concerns } \\
(\mathbf{M} \pm \mathbf{S})\end{array}$ & $\begin{array}{r}\text { energy } \\
(\mathbf{M} \pm \mathbf{S})\end{array}$ & $\begin{array}{c}\text { depressed or } \\
\text { happy mood } \\
(\mathrm{M} \pm \mathrm{S}) \\
\end{array}$ & $\begin{array}{l}\text { the control of emotions and } \\
\text { behaviors } \\
(\mathrm{M} \pm \mathrm{S})\end{array}$ & $\begin{array}{c}\text { relaxation } \\
\text { and tension } \\
(\mathrm{M} \pm \mathrm{S})\end{array}$ & $\begin{array}{c}\text { overall } \\
\text { well-being }\end{array}$ \\
\hline $\begin{array}{l}\text { fathers as self- } \\
\text { employers }(n=63)\end{array}$ & $6.11 \pm 1.35$ & $10.51 \pm 3.54$ & $14.78 \pm 3.21$ & $19.68 \pm 3.74$ & $11.38 \pm 2.32$ & $18.44 \pm 3.34$ & $80.91 \pm 8.88$ \\
\hline $\begin{array}{l}\text { fathers as laid-off } \\
\text { workers }(n=33)\end{array}$ & $6.42 \pm 2.03$ & $10.33 \pm 3.88$ & $15.33 \pm 4.55$ & $20.33 \pm 4.94$ & $11.36 \pm 2.78$ & $18.64 \pm 4.07$ & $\begin{array}{l}82.42 \pm 14.4 \\
4\end{array}$ \\
\hline $\mathrm{t}$ & 10.033 & 1.940 & 5.599 & 2.629 & 0.167 & 0.305 & 8.951 \\
\hline $\mathrm{P}$ & $0.002^{* *}$ & 0.167 & $0.020^{*}$ & 0.108 & 0.684 & 0.582 & $0.004^{* *}$ \\
\hline
\end{tabular}


It can be seen from "Table III" that there is a very significant difference in satisfaction and interest in life and overall well-being between the students with fathers as self- employers and fathers as laid-off workers $(\mathrm{P}>0.05)$, the difference in energy is significant $(\mathrm{P}<0.05)$ and the differences in the rest 4 factors is not significant.

TABLE IV. COMPARISON OF DIFFERENCES BETWEEN STUDENTS WITH FATHERS AS Civil SERVANTS AND FATHERS AS LAID-OFF WORKERS

\begin{tabular}{|c|c|c|c|c|c|c|c|}
\hline & $\begin{array}{c}\text { satisfaction and } \\
\text { interest in life } \\
(\mathrm{M} \pm \mathrm{S})\end{array}$ & $\begin{array}{l}\text { health concerns } \\
\qquad(M \pm S)\end{array}$ & $\begin{array}{l}\text { energy } \\
(M \pm S)\end{array}$ & $\begin{array}{c}\text { depressed or } \\
\text { happy mood } \\
(\mathrm{M} \pm \mathrm{S})\end{array}$ & $\begin{array}{c}\text { the control of } \\
\text { emotions and } \\
\text { behaviors }(M \pm S)\end{array}$ & $\begin{array}{c}\text { relaxation } \\
\text { and tension } \\
(\mathrm{M} \pm \mathrm{S})\end{array}$ & $\begin{array}{c}\text { overall } \\
\text { well-being }\end{array}$ \\
\hline $\begin{array}{l}\text { fathers as civil } \\
\text { servants }(n=56)\end{array}$ & $6.71 \pm 1.64$ & $10.48 \pm 3.44$ & $15.32 \pm 3.19$ & $19.68 \pm 4.28$ & $11.27 \pm 2.51$ & $19.00 \pm 2.91$ & $82.46 \pm 9.89$ \\
\hline $\begin{array}{l}\text { fathers as laid-off } \\
\text { workers }(n=33)\end{array}$ & $6.42 \pm 2.03$ & $10.33 \pm 3.88$ & $15.33 \pm 4.55$ & $20.33 \pm 4.94$ & $11.36 \pm 2.78$ & $18.64 \pm 4.07$ & $\begin{array}{l}82.42 \pm 14.4 \\
4\end{array}$ \\
\hline $\mathrm{t}$ & 3.617 & 2.657 & 6.455 & 0.620 & 0.034 & 1.470 & 5.195 \\
\hline $\mathrm{P}$ & 0.061 & 0.107 & 0.013 & 0.433 & 0.853 & 0.229 & $0.025^{*}$ \\
\hline
\end{tabular}

It can be seen from "Table IV" that there is difference in the cognition of energy and overall well-being between the students with fathers as civil servants and fathers as laid-off workers $(\mathrm{P}>0.05)$, but the difference in cognition of the rest 5 factors is not significant $(\mathrm{P}<0.05)$.

TABLE V. COMPARISON OF DIFFERENCES BETWEEN STUDENTS WITH FATHERS AS TEACHERS AND FATHERS AS LAID-OFF WORKERS

\begin{tabular}{|c|c|c|c|c|c|c|c|}
\hline & $\begin{array}{c}\text { satisfaction } \\
\text { and interest in } \\
\text { life }(M \pm S)\end{array}$ & $\begin{array}{c}\text { health } \\
\text { concerns } \\
(\mathrm{M} \pm \mathrm{S})\end{array}$ & $\begin{array}{l}\text { energy } \\
(\mathbf{M} \pm \mathbf{S})\end{array}$ & $\begin{array}{c}\text { depressed or } \\
\text { happy mood } \\
(\mathrm{M} \pm \mathrm{S})\end{array}$ & $\begin{array}{c}\text { the control of emotions } \\
\text { and behaviors } \\
(\mathrm{M} \pm \mathrm{S})\end{array}$ & $\begin{array}{c}\text { relaxation } \\
\text { and tension } \\
\quad(M \pm S)\end{array}$ & $\begin{array}{c}\text { overall } \\
\text { well-being }\end{array}$ \\
\hline $\begin{array}{l}\text { fathers as teachers } \\
(\mathrm{n}=18)\end{array}$ & $6.78 \pm 1.59$ & $10.33 \pm 2.74$ & $15.22 \pm 2.73$ & $22.56 \pm 3.54$ & $11.06 \pm 2.46$ & $20.06 \pm 3.06$ & $\begin{array}{l}86.00 \pm 10.0 \\
5\end{array}$ \\
\hline $\begin{array}{l}\text { fathers as laid-off } \\
\text { workers }(n=33)\end{array}$ & $6.42 \pm 2.03$ & $10.33 \pm 3.88$ & $15.33 \pm 4.55$ & $20.33 \pm 4.94$ & $11.36 \pm 2.78$ & $18.64 \pm 4.07$ & $\begin{array}{l}82.42 \pm 14.4 \\
4\end{array}$ \\
\hline t & 1.479 & 5.690 & 5.168 & 1.207 & 0.019 & 0.423 & 1.898 \\
\hline $\mathrm{P}$ & 0.230 & $0.021^{*}$ & $0.027^{*}$ & 0.277 & 0.891 & 0.519 & 0.175 \\
\hline
\end{tabular}

It can be seen from "Table $\mathrm{V}$ " that there is significant difference in the cognition of the 2 factors including satisfaction and interest in life and energy between the students with fathers as teachers and fathers as laid-off workers $(\mathrm{P}>0.05)$, but the difference in cognition of the rest 5 factors and overall well-being is not significant $(\mathrm{P}<0.05)$.

TABLE VI. COMPARISON OF DIFFERENCES BETWEEN COLLEGE STUDENTS WITH FATHER FARMING AND FATHERS AS SELF-EMPLOYERS

\begin{tabular}{|c|c|c|c|c|c|c|c|}
\hline & $\begin{array}{c}\text { satisfaction } \\
\text { and interest in } \\
\text { life }(M \pm S)\end{array}$ & $\begin{array}{c}\text { health } \\
\text { concerns } \\
(\mathbf{M} \pm \mathbf{S}) \\
\end{array}$ & $\begin{array}{r}\text { energy } \\
(M \pm S)\end{array}$ & $\begin{array}{c}\text { depressed or } \\
\text { happy mood } \\
(\mathrm{M} \pm \mathrm{S}) \\
\end{array}$ & $\begin{array}{l}\text { the control of emotions } \\
\text { and behaviors } \\
(\mathrm{M} \pm \mathrm{S})\end{array}$ & $\begin{array}{c}\text { relaxation } \\
\text { and tension } \\
(\mathrm{M} \pm \mathrm{S})\end{array}$ & $\begin{array}{c}\text { overall } \\
\text { well-being }\end{array}$ \\
\hline $\begin{array}{ll}\text { fathers } & \text { farming } \\
(\mathrm{n}=136)\end{array}$ & $6.58 \pm 1.60$ & $9.99 \pm 3.42$ & $14.74 \pm 3.69$ & $19.19 \pm 4.30$ & $11.27 \pm 2.17$ & $18.16 \pm 3.30$ & $79.93 \pm 9.41$ \\
\hline $\begin{array}{l}\text { fathers as self- } \\
\text { employers }(n=63)\end{array}$ & $6.11 \pm 1.35$ & $10.51 \pm 3.54$ & $14.78 \pm 3.21$ & $19.68 \pm 3.74$ & $11.38 \pm 2.32$ & $18.44 \pm 3.34$ & $80.91 \pm 8.88$ \\
\hline $\mathrm{t}$ & 7.586 & 0.215 & 1.406 & 2.581 & 1.984 & 0.098 & 0.035 \\
\hline $\mathrm{P}$ & $0.006^{* *}$ & 0.643 & 0.237 & 0.110 & 0.161 & 0.755 & 0.851 \\
\hline
\end{tabular}

It can be seen from "Table VI" that there is a very significant difference in the cognition of satisfaction and interest in life between the students with fathers farming and fathers as self-employer ( $\mathrm{P}>0.05)$, but the difference in cognition of the rest 5 factors and overall well-being is not significant $(\mathrm{P}<0.05)$

TABLE VII. COMPARISON OF DIFFERENCES BETWEEN STUDENTS WITH FATHERS FARMING AND FATHERS AS LAID-OFF WORKERS

\begin{tabular}{|c|c|c|c|c|c|c|c|}
\hline & $\begin{array}{c}\text { satisfaction and } \\
\text { interest in life } \\
(M \pm S)\end{array}$ & $\begin{array}{c}\text { health } \\
\text { concerns } \\
(\mathbf{M} \pm \mathbf{S}) \\
\end{array}$ & $\begin{array}{l}\text { energy } \\
(\mathbf{M} \pm \mathbf{S})\end{array}$ & $\begin{array}{c}\text { depressed or } \\
\text { happy mood } \\
(\mathrm{M} \pm \mathrm{S})\end{array}$ & $\begin{array}{c}\text { the control of } \\
\text { emotions and } \\
\text { behaviors }(M \pm S)\end{array}$ & $\begin{array}{c}\text { relaxation and } \\
\text { tension } \\
(M \pm S)\end{array}$ & $\begin{array}{c}\text { overall well- } \\
\text { being }\end{array}$ \\
\hline $\begin{array}{ll}\text { fathers } & \text { farming } \\
(\mathrm{n}=136) & \end{array}$ & $6.58 \pm 1.60$ & $9.99 \pm 3.42$ & $14.74 \pm 3.69$ & $19.19 \pm 4.30$ & $11.27 \pm 2.17$ & $18.16 \pm 3.30$ & $79.93 \pm 9.41$ \\
\hline $\begin{array}{l}\text { fathers as laid-off } \\
\text { workers }(n=33)\end{array}$ & $6.42 \pm 2.03$ & $10.33 \pm 3.88$ & $15.33 \pm 4.55$ & $20.33 \pm 4.94$ & $11.36 \pm 2.78$ & $18.64 \pm 4.07$ & $82.42 \pm 14.44$ \\
\hline $\mathrm{t}$ & 3.082 & 3.468 & 2.629 & 0.380 & 2.085 & 0.732 & 10.255 \\
\hline $\mathrm{P}$ & 0.081 & 0.064 & 0.107 & 0.539 & 0.151 & 0.393 & $0.002 * *$ \\
\hline
\end{tabular}

It can be seen from "Table VII" that there is no significant difference in the cognition of the six factors of 
overall well-being between the students with fathers farming and fathers as laid-off workers $(\mathrm{P}>0.05)$, but there is a very significant difference in overall well-being $(\mathrm{P}<0.05)$.

\section{CONCLUSION}

From the survey results of the influence of father's occupation on the subjective well-being of college students with left-behind experience, the score of subjective wellbeing of college students with left-behind experience with the father as teacher is highest, followed by those with fathers as civil servants, and those with fathers as selfemployers. The score of subjective well-being of college students with left-behind experience with fathers farming at home is the lowest. To a certain extent, it shows that father's occupation has an impact on the subjective well-being of college students with left-behind experience. The father's occupation not only has an impact on the subjective wellbeing of college students with left-behind experience, but the influence may run through their life. In the conventional sense, a father is the supporter of a family and the center of a family, who mainly creates rich material conditions for the child's growth. Fathers who are engaged in teachers, civil servants, and self-employers may have higher education degree, economic income, and social status. Most of them do not leave their homes to rush to make living, but live with their children and provide a harmonious and warm family environment for children. Children living in a happy family will feel very happy. The fathers who are teachers and civil servants have a good job, so they are confident and optimistic. This kind of emotion affects the child's emotions invisibly; at the same time, because of their work, they are often rational and optimistic when dealing with various difficulties and problems. This kind of resolute and optimistic attitude makes children form the optimistic and bright characteristic unconsciously. In the process of growth, the biggest influence on children is his father, and father's career will affect the happiness of the child's life.

The results show that there is very significant difference in the overall well-being of college students with left-behind experience with the father as self-employers and fathers as laid-off workers, fathers farming at home and fathers as laidoff workers $(\mathrm{P}<0.01)$. The score of college students with leftbehind experience with fathers as self-employers is higher than score of those with fathers as laid-off workers. Perhaps fathers as self-employers have a strong ability to adapt to the market economy with active thinking, and can create richer economic conditions for the family, so the overall happiness of the children is higher; fathers as laid-off workers are mostly inferior, introverted, and not good at communicating with children with low degree of education and no skill, so the overall happiness of their children is lower. The score of overall happiness of college students with left-behind experience with fathers farming at home is lower than that of college students with left-behind experience with fathers as laid-off workers. The father who farms at home is perhaps old and frail with lower education degree and no skill. Such a father will undoubtedly make the whole family worse, let alone bringing happiness to children; the fathers as laid-off workers perhaps live in the town, but they may be stronger than the father who farms at home. There was a significant difference in the overall well-being of college students with left-behind experience with fathers working and fathers farming at home, fathers working and fathers as laid-off workers $(\mathrm{P}<0.05)$. The fathers, who work outside the home in a modern city with rapid development, opened their eyes, increased their knowledge and talents, and activated their thinking. They are more confident and open-minded than the fathers as laid-off workers and fathers farming at home. Fathers in this group have higher expectation for college students with left-behind experience, and their overall wellbeing is stronger. The difference in the overall happiness of college students with left-behind experience with fathers as teachers and father as laid-off workers, those with fathers farming at home and fathers as self-employers is not significant $(\mathrm{P}>0.05)$, which has no statistical significance. It may be caused by the errors in investigation.

\section{REFERENCES}

[1] Guo Lulu. Parents' influence on children's career choice[J]. Journal of Jiyuan Vocational and Technical college, 2009(04): 82.

[2] Zhang Zuoji. Regulations in scales of Behavior medical science [J], Chinese Journal of Behavior medical science, 2001(special issue): 2038

[3] Li Yexuan. The influence of the self-control of preschool children [D], Journal of Zhejiang Sci-Tech University, 2014

[4] Fan Xinhua el at. Adverse family situation and the mental adaptation of left behind children: the media of psychological capital [J]. ChineseJournalofClinicalPsychology, 2018, 26(02): 28 